\title{
Sanitation at the Slaughterhouse and the Hygiene of Food of Animal Origin
}

\author{
Mária Vargová ${ }^{1}$, František Zigo ${ }^{2 *}$, Katarína Veszelits Laktičová ${ }^{3}$ \\ ${ }^{1}$ Department of the Environment, Veterinary Legislation and Economy, University of Veterinary Medicine and Pharmacy \\ Košice, Slovakia \\ Email: maria.vargova [AT] uvlf.sk \\ ${ }^{2}$ Department of Nutrition and Animal Husbandry, University of Veterinary Medicine and Pharmacy \\ Košice, Slovakia \\ ${ }^{*}$ Corresponding author's email: frantisek.zigo [AT] uvlf.sk \\ ${ }^{3}$ Department of the Environment, Veterinary Legislation and Economy, University of Veterinary Medicine and Pharmacy \\ Košice, Slovakia \\ Email: katarina.veszelitslakticova [AT] uvlf.sk
}

\begin{abstract}
Nowdays, one of the most important issues is the issue of food safety. There are many problems with the control of food safety and creation of appropriate legislation that protects food of animal origin. Hygiene and sanitation should be effectively applied and should be controlled at each step during production in food processing plants. The aim of study was to evaluate the surface microorganisms in the monitored parts of the slaughterhouse before slaughter and during slaughter but also after disinfection by disinfectant Virkon S. Disinfectant was used in a $1 \%$ concentration and applied by spraying. Virkon $S$ was effective on all monitored surfaces except the table for organs, where were detected $2 \times 10^{2}$ colony forming units per $10 \mathrm{~cm}^{2}$ of total count of bacteria, $2 \times 10^{2}$ colony forming units per $10 \mathrm{~cm}^{2}$ of coliform bacteria and $1 \times 10^{2}$ colony forming unit per $10 \mathrm{~cm}^{2}$ of moulds after disinfection. The sanitation program should be thoroughly planned, actively enforced, and effectively supervised. Disinfection has its meaning since, everything that comes into contact with the raw material can contribute to outbreaks of food borne illness.
\end{abstract}

Keywords—-Disinfectant Virkon S, Microbiological swabs, Slaughterhouse, Hygiene, Disinfection

\section{INTRODUCTION}

Sanitation is the process which provides conditions that will ensure safe and wholesome products for human consumption. Appropriate sanitation and selection of proper and effective disinfectant is based on the knowledge of the resistance of microorganisms to the effect of used disinfectant, the efficacy of the disinfectants themselves and the impact on the environment [1]. Sanitation at a slaughterhouse requires the necessary adaptation and close links to individual production processes and technologies in order to ensure the health safety of food of animal origin and consequently to reduce the risk of production affected by poor hygiene of the plant.

The slaughterhouse is an establishment used for slaughtering of animals whose meat is intended for human consumption. Food business operators must ensure that the construction, layout and equipment of slaughterhouses where domestic ungulates are slaughtered comply with the requirements of Regulation (EC) No 853/2004 of the European Parliament and of the Council [2].

To ensure the quality of products in food operations according to HACCP requirements, the decisive factor is the control of hygiene and quality of cleaning of premises [3]. Microorganisms found in production facilities are part of the microbial contamination of the finished product [4]. The increased number of microorganisms, or the occurrence of contaminating microflora, represent the final consequence of incorrectly performed cleaning and disinfection [5].

The primary problem lies in the imperfect removal of organic residues in food production, from technological equipment, or from the working environment. Unremoved organic matter is a suitable nutrient medium for the multiplication of microorganisms, leading to undesired contamination [6]. Great emphasis is therefore placed on the whole complex of quality assurance, including production hygiene. In this system, a well-developed and functional sanitation regime has a leading place, the integral part of which is cleaning and disinfection. Sanitation is a complex of activities providing hygienic and anti-epidemiological care for food and hygiene during their processing [7]. Food sanitation includes decontamination, disinfection, rat control and insect control [8].

\section{MATERIALS AND METHODS}

\subsection{Characteristics of slaughterhouse}

In the study we focused on the evaluation of the level of hygiene in a small-capacity slaughterhouse with a 
maximum weekly capacity of 5 large livestock units (LU). This slaughterhouse is located in the Košice region.

\subsection{Microbiological control of effectiveness of disinfection}

Evaluation of the sanitation was performed with microbiological swabs, which were taken from an area of 10 $\mathrm{cm}^{2}$ into $10 \mathrm{ml}$ of sterile saline solution and processed by the classical microbiological method. Swabs from individual surfaces (Figures 1, 2, 3) were taken before and during slaughter and after disinfection with Virkon S. The suspension was inoculated on nutrient agar - Meat peptone agar (MPA) for total count of bacteria (TCB), Endo agar (EA) for coliform bacteria (CB) and Sabouraud agar (SA) for yeast and moulds in the amount of $0.1 \mathrm{ml}$. The plates were incubated in a thermostat for 24 hours at $37{ }^{\circ} \mathrm{C}$ (EA and MPA) and for 72 hours at room temperature (SA), followed by incubation of the grown colonies. The procedure according to the valid ISO standards $[9,10,11]$. was used to determine the total count of bacteria, coliform bacteria and moulds. Individual species of microorganisms were expressed in CFU (colony forming units).

\subsection{Characteristics of disinfectant Virkon $S$}

The evaluated disinfectant Virkon $\mathrm{S}$ was used in liquid form, applied by spraying in $1 \%$ concentration without heating, the treatment time was 60 minutes. Virkon $S$ is a multi-purpose disinfectant, a stabilized mixture of peroxide compounds, surfactants, organic acids and inorganic buffer. It contains potassium peroxymonosulphate used as an oxidising agent, sodium dodecylbenzenesulphonate (anionic surfactant), sulphamic acid and inorganic buffers. Virkon S is recommended for use as a disinfectant on hard surfaces in livestock facilities and in transport.

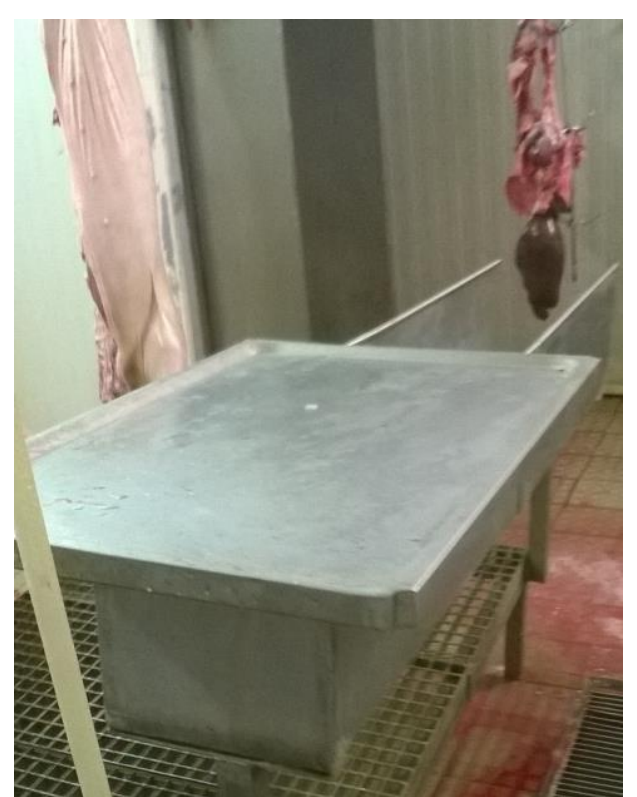

Figure 1: Knife grinder

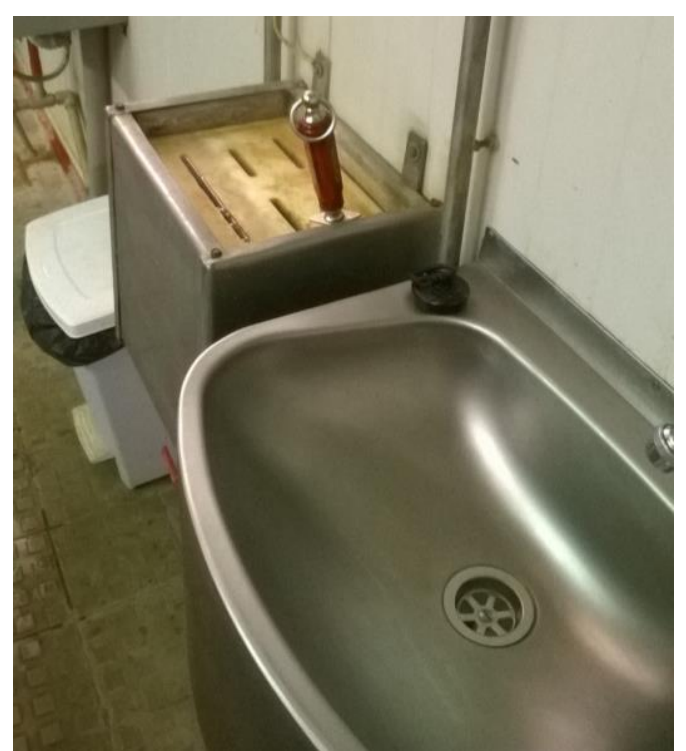

Figure 2: Table for organs

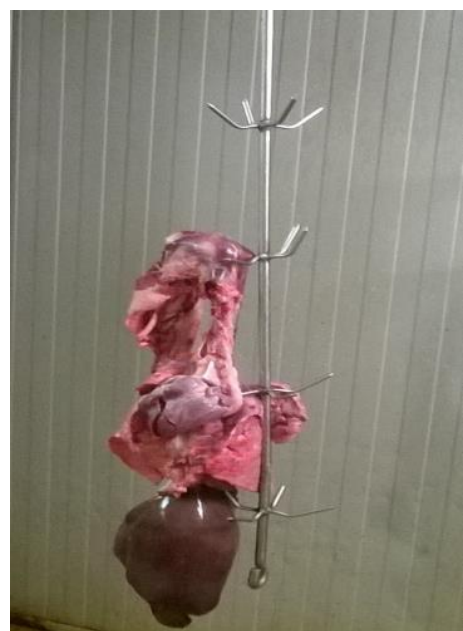

Figure 3: Hanger for viscera 


\section{RESULTS}

The effect of the disinfectant Virkon $\mathrm{S}$ in $1 \%$ concentration on the monitored surfaces (table for organs, hanger for viscera, knife grinder) before and during slaughter as well as after disinfection is shown in Table 1. Virkon $\mathrm{S}$ was effective on a hanger for viscera and knife grinder, where there were no bacteria after disinfection, but the presence of monitored microorganisms was confirmed on a table where $2 \times 10^{2} \mathrm{CFU} / 10 \mathrm{~cm}^{2}$ of total count of bacteria, $2 \times 10^{2}$ $\mathrm{CFU} / 10 \mathrm{~cm}^{2}$ of coliform bacteria and $1 \times 10^{2} \mathrm{CFU} / 10 \mathrm{~cm}^{2}$ of Moulds after disinfection were detected.

Table 1: Effect of disinfectant Virkon S on evaluated surfaces before, during slaughter and after disinfection

\begin{tabular}{|c|c|c|c|c|}
\hline \multirow{4}{*}{$\begin{array}{c}\text { Before } \\
\text { slaughter }\end{array}$} & $\begin{array}{c}\text { Table } \\
\left(\mathrm{CFU} / 10 \mathrm{~cm}^{2}\right)\end{array}$ & $\begin{array}{c}\text { Hanger for viscera } \\
\left(\mathrm{CFU} / 10 \mathrm{~cm}^{2}\right)\end{array}$ & $\begin{array}{c}\text { Knife grinder } \\
\left(\mathrm{CFU} / 10 \mathrm{~cm}^{2}\right)\end{array}$ \\
\cline { 2 - 5 } & $\mathrm{TCB}$ & $5 \times 10^{2}$ & 0 & 0 \\
\cline { 2 - 5 } & Moulds & $1 \times 10^{2}$ & 0 & 0 \\
\hline \multirow{4}{*}{ After slaughter } & $\mathrm{TCB}$ & $2,5 \times 10^{3}$ & 0 & 0 \\
\cline { 2 - 5 } & $\mathrm{CB}$ & $1 \times 10^{3}$ & $5 \times 10^{2}$ & $1,2 \times 10^{3}$ \\
\cline { 2 - 5 } & Moulds & $3 \times 10^{2}$ & $1 \times 10^{2}$ & 0 \\
\hline \multirow{2}{*}{$\begin{array}{c}\text { After } \\
\text { disinfection }\end{array}$} & $\mathrm{TCB}$ & $2 \times 10^{2}$ & $1 \times 10^{2}$ & 0 \\
\cline { 2 - 5 } & $\mathrm{CB}$ & $2 \times 10^{2}$ & 0 & 0 \\
\cline { 2 - 5 } & Moulds & $1 \times 10^{2}$ & 0 & 0 \\
\hline
\end{tabular}

Abbreviations: CFU - colony forming units, TCB - total count of bacteria, $\mathrm{CB}$ - coliform bacteria

\section{DISCUSSION}

Hygienic condition at the slaughterhouse is one of the key factors in the production of hygienically flawless products [12]. A slaughterhouse is a device used to kill animals whose meat is intended for human consumption. In accordance with Regulation (EC) No 853/2004, food business operators are required to ensure that the layout and equipment of slaughterhouses comply with requirements of this Regulation. Slaughterhouses must be equipped with facilities for disinfecting tools with hot water at a temperature of at least $82{ }^{\circ} \mathrm{C}$ or an alternative system having the same effect.

A well-planned and implemented sanitation program in the slaughterhouse premises is very important for achieving the required hygienic standard. Sanitation is the process of providing appropriate hygienic conditions to ensure a safe and healthy product intended for human consumption, which includes hygienic precautions regarding personal hygiene, process hygiene, cleaning and disinfection [13]. The most objective indicator of the level of hygiene and sanitation is the detection of microbial contamination, which allows to evaluate the effectiveness of the disinfectant used, as well as the effectiveness of mechanical cleaning, which significantly affects the effectiveness of sanitation and take the necessary measures to improve hygiene [14]. Microorganisms detected after disinfection are generally more resistant and can pose a potential problem in terms of food safety or food degradation [13].

Failure of the disinfection may be due to the disinfectant selected being ineffective, the disinfectant being used incorrectly, or the environmental factor being affected. Disinfectants can be affected by several environmental factors, such as temperature, $\mathrm{pH}$, or the presence of organic matter [15]. Disinfectants are not universally toxic to microorganisms, but to various degrees interfere with the metabolism of microorganisms and their enzymes [16]. The most objective method of evaluating the effectiveness of disinfection is microbiological control. The use of effective disinfectants minimizes product contamination, increases shelf life and reduces the risk of foodborne illness [17].

\section{CONCLUSION}

From the achieved results, it is clear, that the sanitation provided by the disinfectant Virkon S, used in $1 \%$ concentration, in the evaluated slaughterhouse was effective, as the evaluated disinfectant achieved a decrease in the number of monitored microorganisms and thus ensured a sufficient level of hygiene. When obtaining health and hygienically safe raw materials, the main prerequisite is the application of the principles of hygiene and thorough sanitation in operation, associated with cleaning and disinfection. The microorganisms present in the production premises form part of the microbial contamination of the finished product, since they are present on the floors, walls and surfaces of the technological equipment which come into direct contact with the raw material. Failure to respect and violate this presumption may result in primary or secondary contamination of food and consequently endanger the health of the consumer.

\section{ACKNOWLEDGEMENT}

This work was supported by Slovak grant KEGA no. 004UVLF-4/2020. 


\section{REFERENCES}

[1] Vargová M., Veszelits Laktičová K., Hromada R., Cimboláková I., Uher I., Papajová I. Sanitation and the environment. Intechopen. 2020.

[2] Regulation of the European Parliament and of the Council (ES) No. 853/2004 laying down specific hygiene rules for food of animal origin.

[3] Vojtaššák J. Hygiene control with Lightning MVP detector. Maso, vol. 14, pp. 33-35, 2003.

[4] Forsyte S.J. The microbiology of Safe Food. Blackwell Science, ISBN 0-632-05487-5, pp. 412-414, 2000.

[5] Podstatová H. Microbiology - epidemiology - hygiene I. Olomouc Opava, 2001.

[6] Hofmann, I. Sanitation measures and proper sanitation activities are of exceptional importance in meat operations. Maso, vol. 1, pp. 19-22, 2000.

[7] Ondrašovičová O., Vargová M., Ondrašovič M., Biswencel H., Kašková A., Nagy J. Sanitation in meat processing plants. Proceedings of the seminar on meat preservation. Skaský Dvůr, pp. 51-55, 2003.

[8] Cwiková O., Holický V. Evaluation of the level of hygiene and efficiency of sanitation in a food company. Food safety and control. Proceedings of an international scientific conference. Nitra, ISBN 976-80-552-0027-9, pp. 58, 2008.

[9] ISO Standard 18593-2004: Microbiology of food and animal feeding stuffs: Horizontal methods for sampling techniques from surfaces using contact plates.

[10]ISO Standard 4832-2006: Microbiology of food and animal feeding stuffs: Horizontal method or the enumeration of coliforms.

[11]ISO Standard 21527-2008: Microbiology of food and animal feeding stuffs: Horizontal method for the enumeration of yeasts and moulds.

[12] Štefkovičová M. Disinfection and sterilization, theory and practice II, Vrana, s.r.o., Žilina, pp. 90-92, 2007.

[13]Langsrud S., Sidhu M.S., Heir E., Holck A.L. Bacterial disinfectant resistance - a challenge for the food industry. International Biodeterioration \& Biodegradation, vol. 51, no. 4, pp. 283-290, 2003.

[14] Gibson H., Taylor J.H., Hall K.E., Holah J.T. Effectiveness of cleaning techniques used in the food industry in terms of the removal of bacterial biofilms. Journal of Applied Microbiology, vol. 87, pp. 41-48, 1999. https://doi.org/10.1046/j.1365-2672.1999.00790.x

[15] Singh M., Sharma R., Gupta P.K., Rana J.K. Comparative efficacy evaluation of disinfectants routinely used in hospital practice: India. Indian Journal of Critical Care Medicine, vol. 16, no. 3, pp. 123-128, 2012.

[16] Melicherčíková V. Sterilization and disinfection in healthcare, Grada Publishing s.r.o., Praha 1998

[17] Wirtanen G., Salo S. Reviews in Environmental Science and Bio/Technology, vol. 2, pp. 293-295, 2003. 